\title{
EFL Writing Hindrances and Challenges: The case of Second Year Students of English at Djillali Liabes \\ Dr Melouk Mohamed
}

\author{
Senior Lecturer - Department of Foreign Languages \\ Faculty of Letters, Languages and Arts, Djillali Liabes Uniuversity, Algeria \\ melouk1959@gmail.com \\ Dr Merbouh Zouaoui \\ Senior Lecturer - Department of Foreign Languages \\ Faculty of Letters, Languages and Arts, Djillali Liabes Uniuversity, Algeria \\ zmerbouh@yahoo.fr
}

\section{Doi:10.5901/jesr.2014.v4n3p149}

\begin{abstract}
Our students spend from five to seven years learning English upon entering the university system. However, these students struggle with learning fluent English, as well as lack the ability to express themselves through strong and critical writing skills. For instance, the pre- university "Baccalaureate" examination, which includes elements of English as a measurement tool, has often had one of the poorest scores among all subjects; it is the subject where a great number of students fail regardless of their field of study. The present study was conducted with eighty EFL university students taught by the teacher researcher at Djillali Liabes University in the Department of Foreign Languages section of English. Students enter university lacking essential writing prerequisites. They had generally written very little in the form of compositions, essays or papers in English. As subject, English was primarily meant for examinations, whose priority was on grammar and reading comprehension exercises. The "Baccalaureate" candidates had to answer a paper that consisted of three sections: reading comprehension, manipulation of language and written expression. Data analysis revealed that EFL students encountered many writing challenges, particularly those related to language proficiency.
\end{abstract}

\section{Introduction}

Rapid and continued globalization places pressure on many countries to incorporate the use of the English language as either first or second language. Recognizing the status and prestige of the English language, a vast majority of academic institutions now include exposure to the language in their educational curricula. The use of the English language permeates and crosses all academic disciplines, including different sciences, technology, literature and politics. Understanding that the use of the English language is spreading globally, Algerian leaders and educators are working to ensure that it is included as a FL at all levels of education regardless of the learners' disciplines.

Speaking and writing English are of great importance, especially for those students who intend to proceed to higher education. In addition to the English departments in most Algerian universities, many faculty members give considerable attention to teaching English in a variety of subjects, such as journalism, interpreting, political sciences and commerce. Writing is a vital skill and gaining skills and confidence in writing can open up opportunities to and empower learners to take on new roles as citizens within the community. It provides a powerful means as self-expression as well as a support for further learning and research.

\section{Writing Difficulties}

Writing is an important but difficult skill to acquire, a communication skill which is essential in today's information society. The level of difficulty is significantly higher when a foreign language $(\mathrm{FL})$ is involved. Differences in the language structures, the manner of expressing thoughts, writing styles and other culturally varying factors greatly affect the writing of foreign language learners (FLL) (Benson and Heidish, 1995).

Writing is a complex process that allows learners to explore thoughts and make them visible and concrete. It encourages thinking and learning, because it motivates communication and makes ideas available for reflection. When 
ideas are written down, they can be examined, reconsidered, added, rearranged, omitted and/or changed. Novice learners, however, need to practise writing that involves reproducing learned material in order to learn writing conventions of spelling, punctuation, and grammatical agreements.

Hadifield (1992) note three areas of difficulty for the learner in relation to the productive skill of writing. First, the writer cannot consult the reader, for the audience is not immediately present as in the case with speaking. Second, learners suffer from linguistic difficulty in that language used in speech is not the same as writing. In some cases it is simpler-like a shopping list, in others it is more elaborate and formal like in an academic report. The difficulty is more evident for E.F.L learners who are unaware of the discourse patterns inherent in particular types of writing. The last difficulty is cognitive, this relates to the ability to organize ideas on the paper.

\section{Thesis Statement}

When asked about the degree of difficulty in respect to the "Written Expression Module", students often respond saying that the module is extremely difficult. Additionally, students indicate their current level of writing expertise does not coincide with the sentence and grammatical level of the testing instrument. The current two-year programme is not beneficial in helping students with their current writing deficit, nor does it develop their ability to write research papers, and the requisite extended essay in their third year English Degree. The study addresses the following questions:

1. What academic writing skills do students possess upon entering higher education academic institutions?

2. What kind of writing failure do English as foreign language (EFL) university students encounter?

To conduct this research two hypotheses were formulated:

1. Students enter university EFL courses with little academic writing experience in producing paragraphs and/or compositions.

2. The students' writing deficit may be of many types and can have a variety of causes.

It is no surprise that university-level educators are challenged to rethink and revise some of the approaches and goals in teaching writing in order to effectively prepare students to successfully accomplish the extended essay and other research papers. The study was designed as an action research descriptive case study. The researcher assumed his role of participant-observer due to the fact that he was teaching the students in addition to observing and collecting data. Assuming the role of participant-observer enabled him to examine the learners' writing hindrances and challenges.

\section{The Aims of the Study}

The study aims at finding out the students' linguistic and academic needs, their writing habits and learning strategies. It also aims at bridging the gap between the secondary school and the university and later to enable students to produce materials applicable to the design of writing courses in English language teaching (ELT) departments.

The study also focuses on the study and analysis of English university students' inability in comprehensive writing. In addition this study is rather to show and demonstrate the weak prerequisites in written expression the students of English have and to determine the students' needs in learning written expression as well as to investigate students' problems in writing compositions. The study's findings are also expected to provide insight into central issues to teaching/leaning written expression for LMD students of English.

\section{Data Collection}

In order to test the above hypotheses and build validity and triangulation into qualitative study, the researcher has used a variety of data collection tools. In addition to the corpus from former "Baccalaureate" results of English exams papers, he has kept a journal of observation to study and analyze samples of second year English students' writing tests and assignments.

Observing the learners writing gave the teacher the opportunity to gather information from different perspectives, especially when engaged in writing activities and conversing in writing conferences. This observation involved the use of field notes that included different participants writing shortcomings and problems.

\section{Participants}

The participants of this study were undergraduate students. They were selected from two different groups of second year 
students from the English Department of Djillali Liabes University. These students were asked to write an expository composition. They were taking the intensive English courses in the English Department to get a degree in English attending three hours of writing instruction per week for their first two years. Most of them have studied English for seven years in secondary schools. However, as admission to the institution is based on the students' grades in a national examination, namely "Baccalaureate"; the examination consists of a number of subjects matters; they may have had a heterogeneous level of English proficiency at the time of admission. That is, students are not admitted on the basis of their proficiency in English per se, but because of their cumulative grades from the other subject matters.

The purpose of the intensive English course is to develop the students' command of English up to the intermediate level so that they are prepared to take other courses offered in English in the Department. In this intensive course, language skills (listening, speaking, reading and writing) and language elements (vocabulary, grammar and pronunciation) are taught in an integrated manner. Additionally, learning materials are graded and systematized so that the students move progressively into each learning experience. As a prime course, the course provides a basic foundation of English skills important for further courses. Writing exercises in this course are mostly given at the paragraph level. The purpose of writing at a discourse level is to provide an opportunity for them to do more writing. The writing course trains the students to write paragraphs based on model paragraphs of various genres and develop ideas in essays with an emphasis of the organization, coherence cohesion and transitions. The writing course also aims at providing opportunities to write more essays with various techniques of development such as cause and effect, comparison and contrast as well as the development of an argumentative type of writing.

\section{Data Analysis}

Throughout the fieldwork the researcher observed learning in its natural setting. His field notes, therefore, served as one of the primary data sources and helped him identify the specific segments from the vast amount of data as well as the corpus that could illustrate the participants' response activities. Upon the review of the data, some issues arose that he had not anticipated and led to further investigation.

\subsection{Research Question one: Students Writing Prerequisites}

It is worth noting that the "Baccalaureate" examination is the only "visa", which allows students to study for higher education. As studied with the corpus figures taken from this formal examination, the pre-university students suffer from many writing hindrances, which are, most of the time, the main cause for their failure in English as a subject. Students enter university lacking essential writing prerequisites. Before coming to university they had generally written very little in the form of composition essay or papers in English. English as subject was primarily oriented to examinations, which emphasized questions on grammar and reading comprehension exercises as it is shown with this sample group of "Baccalaureate" candidates who had to answer a paper that consisted of three sections: reading comprehension, manipulation of language then written expression. The group consisted of 222 candidates anonymously corrected and randomly selected to point to their weakness areas in English.

Among 222 candidates 130 managed to answer section one: Reading comprehension that is (60.36\%), their marks varied between 03.50 and 07 points, 88 others (39.63\%) however, got less than 03 points. It is worth reminding that this section was scored on 7 points, and no one failed in this section or left it blank.

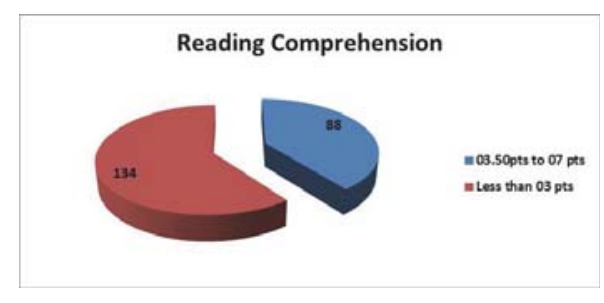

Figure 1. Section one: Reading Comprehension

For section two, mastery of language, out of 222 pupils 195 got less than 04 points that is ( $87.83 \%)$. As far as section three, written expression, is concerned, 134 pupils scored between zero to half a point most of them wrote nothing. 
Those who got 0.50 point, they only wrote notes provided to be expanded in the guided topic or started but did not finish for one reason or another. 79 candidates got between 01 and 02 points. From the whole number (222) only nine pupils managed to get 02.50 points. A lot of them did not write a single line, and simply abandoned and left the written expression section blank. In sum, of the three sections, written expression represented a noticeable failure, which confirms the weak writing prerequisites of pre-university students.

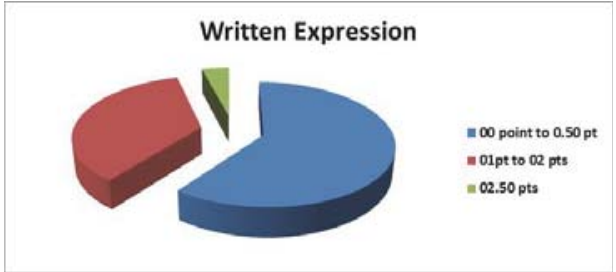

Figure 02. Section three: Written Expression

The problem associated with writing development at the basic sentence level can be traced to the over reliance on multiple choice questions to educate and test secondary pupils. Multiple choice questions (MCQ) are used as primary educational tools because the main purpose of secondary school education is to prepare the pupils for "Baccalaureate" examination Goodman (1993). This overuse of MCQ hinders the acquisition of spoken and written English communicative skills. These practices do not place adequate emphasis on language learning activities that would be productive in developing communicative skills needed to significantly improve sentence and paragraph development proficiency.

\title{
7.2 Research Question Two: Writing Difficulties
}

The findings of the present study regarding the conceptual, rhetorical and linguistic weaknesses in the students' assignments indicate that academic writing can indeed be difficult for Algerian university students on many different levels.

\begin{abstract}
"Writing is frequently a difficult skill for any language user, which is to say that writing presents a fairly challenging task for both native and non-native speakers. For English as a second language, ESL students, it seems fair to say that writing academic papers is particularly difficult." Kroll (1990: 140)
\end{abstract}

In general, the compositions written by the students participating in the study failed in many ways to satisfy the expectations of the researcher. While there were common problems, not all of the students demonstrated the same weaknesses.

\subsubsection{Language Proficiency}

Research indicates that when EFL students are writing in the target language they frequently face a triple challenge: they must master the content and concepts in English, write through a language which they may not fully command and within a cultural context that is completely different from their own. They, therefore, face a number of complex simultaneously occurring dynamics. Furthermore, some of the topics that EFL students are required to write are too difficult, for the majority of these students are still struggling with and worried about composing complete sentences. So they are all the time wrestling with a different language and a different way to express ideas and feelings on a paper. When writing in English, they encounter not only the struggles that writers usually face, but also the challenges for working in a language in which they are not proficient. So these students are often afraid to write and are reluctant to write particularly in examinations because they are marked.

Many students abandon topics of interest because they are unable to express themselves in adequate English; others are preoccupied with producing correct English and will write only whatever they are sure in terms of grammar and syntax or they sometimes just copy from whatever sources they have just read that are relevant to their subjects. Due to limited English vocabulary and grammar students are unable to convey their ideas well, thus affecting the quality and 
content of their writing. Therefore, they are often reluctant and hesitating to share papers in peers writing, because they believe that only teachers can give helpful feedback. While reading and rereading the participants' writings the researcher arrived at the following findings:

\subsubsection{Vocabulary and Grammar}

Among the many language difficulties the students initially encountered were those related to vocabulary like spelling, word choice and wrong words. They could not spell the words, know their meaning or identify their sound representations; these difficulties were serious when thinking in Arabic or in French and did not know the English term. Students found themselves using a limited number of words again and again. One reason for the limited variety of words could be a difference between English and Arabic. If the students think in Arabic even partially, when writing in English, they tend to use a very limited number of corresponding English words and expressions even if they try to translate; there are not always equivalents from one to another.

Apparently, having a good knowledge of grammar- grammar sessions one hour and half twice a week- does not mean that one can use those structures well. There is a gap between "know what" and "know how". Still a lot of students showed many grammatical errors in their writing; the most frequently reported error category was subject-verb agreement. This error is probably due to the fact in Arabic the present tense of a verb does change with all subjects. In English it does not except for the third person singular. Therefore, adding "S" to obtain HE/SHE or "IT" form appears to be hard to perceive and apply in writing. Students' challenges in vocabulary and grammar might be attributed to their lack of reading and writing practice.

\subsubsection{Sentence Structure and Paragraph Development}

English has simple, compound and complex sentences and relative pronouns which allow to build many ideas into one sentence. But the students probably were not used to write complicated sentences in L1 or first FL (French). The shift from habit of writing simple short sentences to writing more complex ones made their writing more challenging.

In fact most of the students were not simply accustomed to using other structures or deliberately avoided using more complicated structures, or they were not very sure about because they feared making errors and being penalized for them. Elaborating more complex sentence was a real hindrance; therefore, there were likely to use more simple sentences instead of one or two compound or complex ones. In other words, composing long sentences was likely to pose risk of making errors and lack of clarity; that what made them looked for refuge in less complicated structures.

Paragraph development was another identified writing weakness of Algerian students. They had difficulty in presenting materials in a logically organized and coherent manner that readers can understand easily. However, the students tended to write around the topic and often leave the readers with the task of interpreting their message in addition to a broad range of material, much of which was not directly related and relevant to the topic of writing.

\subsubsection{Connections between Ideas}

In the writing assignments the students were supposed to identify and develop appropriate links between them since the identification of isolated ideas is not highly valued in any academic writing. Linking ideas and making the transition into new frameworks seemed to have proven very difficult for the students participating in the study. They had much greater difficulty with the development of ideas into more complex ones; most of the time they were just listing points and the appropriate connections between them were often missing. The ideas were presented in isolation, and in most cases this lack of connections was apparent. Students' writing responses looked like a series of separate sentences within the paragraph like a shopping list or telegraphic sentences, and on the whole separate paragraphs rather a complete composition style as it was required. However, with these connection errors communication between the writer and the reader was broken and the interaction was faulty.

\subsubsection{Problems of Transition}

The researcher identified particular problems that the students participating in the study had in making the transition within and between paragraphs in a composition. One of the most important writing problems identified in students' writings was that they did not know what rhetorical pattern to use. In fact, most of the time writing assignments required a 
combination of more than one pattern. In a topic like delinquency or divorce this might need to combine several patterns depended on the way they were addressed. Thus, we notice that illustration, problem/solution and /or definition and the like are all necessary to address the topic thoroughly. The students' writings revealed that they needed to learn that these writing patterns were not rigid rules to follow, but tools that could help them express themselves. Moreover, the students sometimes presented the writing items like in cause and effect in a form of long lists of causes then results lacking expressions like: (this is due to, because since as , as a result, consequently, thus therefore and the like).

\subsubsection{Missing Ideas}

Another type of students' writing problem was, and in many cases, important ideas were missing from their writing responses. In some cases the students' answers provided much other information not required or inappropriate to the topic. In other cases their responses consisted of a hundred rather than three hundred words expected. One of the most important causes to that was the students' neglect to brainstorm and outline in pre-writing phase. This is why many relevant information and ideas were omitted, forgotten or even thought of with a difficulty of judging what to include and/or what not to include. In conclusion the students' responses demonstrated that they did not really understand the subject, or the hierarchical importance of ideas was not respected, which made secondary information took priority over primary ones.

\subsubsection{Style}

Half the of students highlighted more difficulty to produce grammatically correct writing, while the majority found writing with good rhetoric and appropriate style a real challenge that was beyond their reach. Style could be difficult for Algerian students because they were writing in a language, which is different from their native. They did not know the proper sense of how certain vocabulary had to be used appropriately, how the sentence might be organized to achieve the flow of ideas, which was one of the hardest things about writing to make it readable. They sometimes managed to put what they wanted to express on paper mechanically, but it did not flow well. Because these students had little exposure with the target language, writing in good correct English posed a considerable challenge. Moreover, several students were not aware of the written academic style; they used various colloquial expressions in their writing; the most common being contracted forms involving auxiliary verbs such as "wasn't" "didn't" "isn't" and the like.

\section{Recommendations}

In the light of the findings, the present investigation presents some suggestions and their pedagogical implications that might cater for university students' difficulties in writing in general and other sub-skills in particular.

\subsection{Reading writing relationship}

We believe that erecting the link between reading and writing would better students' writing assignments. (Reid, 1993) concludes that the language skills- reading and writing- are both processes of making meaning that involve similar patterns of thinking and similar linguistic components. Both skills trigger schemata about the language, content and form of the topic. They both lead to the exploration of these schemata in discovering meaning (Leki, 1993). Both readers and writers have some kind of drafts of meaning in their minds as they start to read or write. Zamel (1992) also pointed out that reading and writing are both acts of knowing and competence and enhance one another.

\subsection{Showing models}

The integration of the models approach with the process approach can improve the students writing abilities through reading these good writing models. Teachers believe that it is a way to systematically analyze and imitate models commenting on their merits and weaknesses so that students are provided with direction on how to revise and improve their different drafts. 


\subsection{More Time Allotment}

FLL might benefit greatly from simply reducing their course load and progressing more slowly through their degrees. This might allow them to develop their language skills to a higher degree and also to devote more attention to each assignment. Writing, like any exercise, becomes easier and easier when done every day; writers get into a rhythm and find a stride. Kroll (1990) suggested that because non-native speakers have particular difficulty with the code of English, extending the amount of time allotted to write may affect the level of mastery over the different text levels.

\subsection{Mini-Lessons}

Mini lessons are defined as a five to ten minutes writing instruction, which focuses on one particular convention Graves (1985). Teachers select when and what is to be covered in the mini lesson based on their impressions of what the class needs as well as the needs of certain students. At times, whole class lessons are needed and at other times students who require a more focused instruction receive the lesson. Possible mini-lessons to be covered during a writer's workshop may include certain punctuation marks like the use of the comma, outlining paragraphs, organization, capital letters and the like.

\subsection{Conferencing in Writing}

Adequate time for conferencing in the writing workshop is essential for student writing development. Graves (1985) emphasizes that the main purpose of a conference is to encourage student to show what they know and to gain a clearer picture of where their writing is headed. In writing conference, two advantages are identified: (1) the student controls the direction of the learning and (2) the focus is on the student's writing skills. It also enables students to take control and responsibility for their learning. The teachers become more aware of the strengths and weaknesses of individual students and the progress of each student. They believe that conferencing is the means of truly individualizing learning. Graves (1983) states that conferences stimulate learners for they do the work, solve problems, answer questions or discover new information. Conferencing also allows teachers to gain more information about the subject and acquire perspectives on what will help the student.

\section{Conclusion}

From the study tools, the researcher understood that the EFL students' level of writing is unsatisfactory and their language proficiency is rather weak and it needs to be improved to overcome all the other writing sub-skills from the sentence structure to the transitional devices. The students' lack of motivation, interest and reading practice might be among the most important causes to their writing weaknesses in addition to the very limited time instruction. Therefore, something might be done in pre-university education. More importantly, writing with clarity of meaning was probably challenging than written style. In fact misuse of words, no-idiomatic expressions, inappropriate placement of sentence elements, wrong connectives to express relationship and incoherent ideas made their sentences unclear.

Improving students' written performance requires both time and work. It is, then, the role of the teacher to enhance and emphasize its communicative functions. He needs to teach the various sub-skills and deal with its different types: controlled, guided and free. Further, the students' writing process could not end at the teacher's scores and comments, but special correction sessions have to be devoted to discuss and remedy their writing weak areas, and consider their writing needs, styles and strategies. They also have to frame the teaching practices according to the quests of learnercentred education and collaborative teaching/learning, where they act as facilitators and organizers of writing experiences and enable students to develop effective strategies. Thus, more research into the writing ability of these students is needed to identify means of developing the skills needed to effectively produce English writings of adequate quality.

\section{References}

Arndt, V., White, R. (1991). Process Writing. Longman Handbooks for Language Teachers. Longman, UK: Longman Limited.

Babin, Edith \& Harrison Kimberly. (1999). Contemporary Composition Studies: A Guide to Theorists and Terms. Westport: Greenwood Press.

Bachman, L. F. (1995). Fundamental Consideration in Language Testing, New York: O.U.P. 
Bazerman Charles \& Russell David R. (2003). Writing Selves/ Writing Societies. University of California : USA.

Benson, P.J. \& Heidish, P. (1995). "The ESL Technical Expert: Writing Processes and Classroom Practices". In D. Belcher \& G. Braine (Eds.), "Academic Writing in a Second Language": Essays on Research and Pedagogy (pp. 313-30). Norwood; NJ: Ablex.

Betchel, J. (1985). Improving Writing and Learning. Newton, MA: Allyn and Bacon Inc.

Broderick J. P. (2003)The Able Writer: A Rhetoric and Handbook. Virginia :USA

Brown, K (1989). Writing Matters, Hong Kong :C.U.P.

Flower, L. \& Hayes, J. (1981). "A Cognitive Process of Writing". College Composition and Communication, 35, 365-387.

Goodman, Y. (1990). How Children Construct Literacy: Piagetian Perspectives. Newark, DE: International Reading Association.

Graves, D.H. (1985). Writing: Teachers and Children at Work. Portsmouth, NH: Heinemann Education Books

Graves, D.H. (1983). Writing: Teachers and children at work. Portsmouth, NH: Heinemann Educational Books.

Hadfield, J.( 1992). Classroom Dynamics. Oxford: Oxford University Press.

Hairston, M. (1982). "The Winds of Change: Revolution in the Teaching of Writing". College Composition and Communication, 3(1), $76-$ 88.

Harris, J. (1993) Introducing Writing, London: Penguin.

Hillocks. G. Jr. 1986. Research on Written Composition: New Directions For Teaching. Urbana. Illinois: NCRE \& ERIC.

Jupp,T.C. \& Milne, J. (1980). Basic Writing Skills in English, London :Heinemann Books.

Kroll, B. (Ed) (1990). "What Does Time Buy"? In B. Kroll (Ed.). Second Language Writing: Research Insight for the Classroom. Cambridge: Cambridge University Press.

Kroll. B. (1993). "Teaching Writing is Teaching Reading: Training the New Teacher of ESL Composition". in J.G. CARSON \& 1. LEKI (Eds.), Reading in the Composition Classroom: Second Language Perspectives (pp. 6 1-8 1). Boston: Heinle and Heinle.

Lacombe, M.C (1997). "Computers and Writing: Teaching Computer Skills for Writing to Fifth Grade Students." Unpublished Doctoral Dissertation. The Union Institute.

Leki, I. (1991). « Twenty-Five Years of Contrastive Rhetoric's: Texts Analysis and Writing Pedagogies ». TESOL Quarterly, 25(1).p.123143.

-(1993). "Reciprocal Themes in ESL Reading and Writing" In J.G. CARSON \& I. LEKI (Eds.). Reading in the Composition Classroom: Second Language Perspectives (pp. 9-32). Boston. MA: Heinle and Heinle.

-(1995) a. "Coping Strategies of ESL Students in Writing Tasks Across the Curriculum." TESOL Quarterly, 29 (2), 235-60.

-(1995) b. "Good Writing: I Know it When I See it". In D. BELCHER \& G. BRAINE (Eds), "Academic Writing in a Second Language:" Essays on Research and Pedagogy (pp. 23-46). Norwood, NJ: Ablex.

Leki, I. \& Carson, J.G. (1994). Students' Perceptions of EAP Writing Instruction and Writing Needs Across Disciplines. TESOL Quarterly 2:1.

Pincas, A. (1982). Teaching English Writing. London :McMillan.

Raimes, A. (1987). Techniques in Teaching Writing, New York: O.U.P.

Zamel, V. (1992.) "Writing One's Way into Reading". ESOL Quarterly, 26, 463.483. 